\title{
Australia's Carbon Tax: A Sheep in Wolf's Clothing?
}

\author{
Clive L. Spash* \\ Alex Y. Lo**
}

\begin{abstract}
${ }^{1}$
The Australian Government has produced a $\mathrm{CO}_{2}$-equivalent tax proposal with a difference: it is a short prelude to an emission trading scheme that will allow the increasing rate of emissions to continue, while being a net cost to the Treasury. That cost extends to allowing major emitters to make guaranteed windfall profits from pollution permits. The emission trading scheme suffers numerous problems, but the issues raised in this article show that taxes can also be watered down and made ineffectual through concessions. Taxpayers will get no assets from the billions of dollars to be spent buying-off the coal generators or other polluters. The scheme seeks to stimulate private investors to create an additional 12 per cent in renewable electricity generation by 2020. A really serious emissions reducing alternative would need to create a nationalised electricity sector with 100 per cent renewable energy within a decade. We explore the limitations of Australia's carbon tax plan which has now passed into law.
\end{abstract}

\section{JEL Codes: Q52; Q54; Q56; Q58}

\section{Keywords}

Australia; carbon taxation; climate change; emission trading; greenhouse gases; regulation; renewable energy.

\section{Introduction}

Since they were proposed at the start of the nineteenth century, pollution taxes have been part of the economist's tool kit for internalising the social costs of environmental damages. The aim of a tax on air pollutants is to reduce atmospheric concentrations by creating a cost charged for emissions and an incentive to use environmental resources more efficiently. Thus, for greenhouse gases (GHGs) a tax should penalise polluters, provide an incentive for lowering the GHG intensity of energy production and consumption, and raise social welfare by avoiding social and environmental damages that would otherwise occur.

Yet such taxes have often proven politically controversial and hard to implement. In the area of public policy on climate change this has led to a preference

\footnotetext{
* WU Vienna University of Economics and Business, Austria; Norwegian University of Life Sciences, Norway

** Griffith School of Environment, Griffith University, Australia
} 
for emissions trading due to its supposed competitive market-like qualities (Lohmann 2006), and despite that approach having even more serious problems than taxes (Spash 2010). This has also led to the language of the market being used inappropriately as a rhetorical device. Rather than the term 'tax', a neoliberally more acceptable term 'price' is increasingly employed, as if the idea were to establish a market rather than a government regulated charge.

In Australia, the rejection of an emissions trading scheme (ETS) and a failed attempt to tax profits in the mining sector led to the threatened downfall of the Labor Government of Kevin Rudd and an internal party coup by Julia Gillard in part to placate mining interests. Now the Labor Government under Gillard, in coalition with the Greens, has proposed a means of making polluters pay which is meant to steer through the political minefield. The official proposal states: 'For the first three years, the carbon price will be fixed like a tax, before moving to an emissions trading scheme in 2015' (Australian Government 2011: vii). Official documents and media communications have been carefully crafted to avoid the unpopular name tax in preference for price. However, in a major speech to the National Press Club, the Prime Minister stated that this was a 'temporary carbon tax' (Gillard 2011) and the Treasurer, in response to media questioning on the design, had to admit 'that [design] is a carbon tax, that is true' (Swan 2011). The Minister for Climate Change and Energy Efficiency has also referred to the scheme as a 'carbon tax for a short period of time' (Combet 2011).

The reason for this sensitivity is that a serious GHG emissions tax would impact across society, and it would need to do so to be effective. If action is deemed necessary then it must be sufficient to address the problem and that means stabilising global GHGs in the upper atmosphere. Australia, as the highest per capita source of $\mathrm{CO}_{2}$ emission ${ }^{2}$, is actually committed by the Kyoto Protocol to increasing emissions by 8 per cent over 1990 levels. ${ }^{3}$ Even this it has failed to achieve and now is merely limiting itself to reducing the rate of increase by choosing a base of 5 per cent reductions on 2000 levels. As such the targets have been extremely minimal compared to the 80 per cent emissions reductions on 1990 levels stated as needed by 2050 in order to stand a chance of avoiding temperature rises above $2^{\circ} \mathrm{C}$ (Parry et al. 2008). Yet the pretence remains that GHGs can be controlled sufficiently without disturbing the current economic system, that growth can be maintained as usual and some straightforward market pricing will provide the answer to the threat from human induced climate change.

In this article we review and assess the economics of the GHG taxation, pricing and regulation policy debate in Australia. The next section addresses the theoretical promise of a taxation approach to pollution. We then turn to the Australian scheme and discuss how it weighs up against the expected benefits of a normal pollution tax and why it appears set to be ineffective, highly costly and mainly of financial benefit to big polluters. This leads into a discussion section where we explore what is needed to change Australia to a low GHG emissions economy and how this might be achieved within a decade. Our conclusions emphasise the need for a move away from the current approach dominated by market rhetoric, appeasing powerful polluters and corporate interest groups, 
moving towards taxation designed to fund structural change, and create public assets, not private profits.

\section{Advantages of and Challenges for a GHG Tax}

Pollution is conceptualised in economic theory as a minor aberration on an otherwise perfectly functioning market system (Spash 2010). A defining principle of welfare economics, originating in the work of Arthur Pigou (1920), is that public policy should involve estimation of the social damages of negative externalities in monetary terms, and subsequent imposition of a tax to correct such market price failures. Such a Pigovian tax policy requires that firms, whose economic activities have shifted costs onto society, should pay for the damages they cause.

For the case of human induced climate change, GHGs are emitted into the atmosphere without cost to the polluter, but the resulting damages from climate change will be borne by a wide range of victims across time and space (Spash 2002). GHG taxation aims to correct this market failure by making the value of social damages internal to the polluters' decisions. The approach has been advocated by environmental economists as addressing the need to reduce GHGs to an efficient level while avoiding major disruption to economic systems (Oates 1995; Pearce 1991). That efficient level is one where the monetary costs involved in achieving regulation are weighed against the monetary benefits of avoiding pollution damages. However, calculating those monetary costs and benefits for human induced climate change, especially in the detail required by economic theory, is impossible (Spash 2002), and all attempts to do so merely result in rhetoric and conjecture (Spash 2007).

In this regard, a major problem for achieving GHG control is the absence of victims because, unlike many other pollutants, the damages are expected ones that will occur in the future. In addition, the cause-effect relationships are complex, making any change in climatic events (for example, an increase in frequency or scale of storms, droughts or floods) hard to recognise and link directly to human induced climate forcing. The fear amongst those who take the problem seriously is that this will be used to jusdtify inaction until such events become overwhelming and so the opportunity to avoid the problem has been lost.

A further complication for an economically efficient regulation aiming to control human induced climate change is the fact that several different emissions contribute to the problem. Atmospheric concentrations of carbon dioxide $\left(\mathrm{CO}_{2}\right)$ contribute about half the human induced climate forcing. The other half is due to a variety of human emissions of GHGs, such as methane, nitrous oxide, chlorofluorocarbons, perfluorocarbon, hydrofluorocarbons and sulphur hexafluoride. Economic efficiency requires that GHG control should relate to the most net cost-effective source first. The regulatory approach in this regard has generally been to calculate everything in the same terms and to convert all GHGs into $\mathrm{CO}_{2}$-equivalent emissions. This is not a straightforward calculation but rather requires taking into account such things as transmission to the upper atmosphere, the expected life of gases in the upper atmosphere, and their potential for trapping ultra-violet radiation. 
Where pollution emissions are directly related to an input (i.e., factor of production) in the industrial process, choosing to levy a tax on either emissions or a production input can be equally effective. Thus taxation on coal could be undertaken instead of taxation on emissions from coal fired power stations. For $\mathrm{CO}_{2}$ emissions, this requires knowing the correspondence between fossil fuel combustion and emissions into the atmosphere after combustion. While, again, not a straight forward calculation - subject to the input quality, treatment and combustion technology involved - the tendency has become to talk of a carbon tax, rather than $\mathrm{CO}_{2}$-equivalent emissions tax.

Some gases (e.g., chlorofluorocarbons) are hundreds of thousands times more powerful at forcing climate than $\mathrm{CO}_{2}$ but may be produced in relatively small quantities and are artificially constructed (i.e. synthetic) rather than naturally occurring. In these cases a straightforward ban would be the most effective way to remove the emissions. However, the rise of neo-liberalism has made such direct regulation, and use of government power, politically unpopular and raised the goal of efficiency above effectiveness. Industrial producers may emphasise that the possibilities for substitution are few and the costs (in jobs and profits) to the economy high, while they demand government not intervene in the supposedly efficient free market system. Thus a political negotiation occurs in which, at best, a nominal charge may be levied while major polluters are made exempt from, or given financial rewards for, complying with taxation. This of course does not address the pollution problem of concern.

Despite these issues, GHG taxation is considered to be a robust public policy measure for several reasons. According to Ekins and Barker (2001), such a tax:

- Tackles an accepted economic problem, i.e. a damaging externality;

- Generates revenues that are expected to grow with income;

- Tends to be simple and cheap to administer;

- Can stimulate energy savings, innovation and investment in clean technology and so economic growth;

- Is likely to have minimal regressive side-effects allowing compensation using a small fraction of the expected revenues. ${ }^{4}$

GHG taxation has also been described as being able to achieve a 'double dividend'. The double dividend hypothesis refers to simultaneously: (i) lowering the costs of pollution control via innovation and (ii) reducing the overall economic costs associated with the tax system (Goulder 1995; Oates 1995; Parry 2001). Let us consider each claim in turn.

From the perspective of neoclassical economics, development of completely new technologies is driven by expected profits. Businesses are rational investors, and the size of their investment depends on the opportunity cost of capital and the expected return from research and development (IPCC 2001). Technological improvements are seen to occur continually through the accumulation of knowledge capital and selection of better techniques in response to a changing economic and legislative context. Carbon taxes are viewed as a continuous incentive to adopt ever cleaner technology (Pearce 1991). The first dividend of GHG taxation hinges upon the existence of such a positive relationship between price 
and technical innovation - i.e. the higher the tax rate, the more significant the incentives for innovation (OECD 2010).

The first dividend also relies upon a higher cost, for GHG intensive energy generation and products, encouraging profit-seeking firms and budget constrained households to look towards more energy-efficient production and consumption. The expectation is that a tax will stimulate lower cost alternatives and the development of new low-carbon technologies. This assumes that the rate and direction of technical innovation respond to changes in demand and relative factor prices (Löschel 2002). There appears to be some published support for the claim at an aggregate level (Jaffe and Stavins 1995; Popp 2002).

However, others question the potential of market forces to stimulate technical innovation. For example, the Intergovernmental Panel on Climate Change (IPCC) recognises the potential but also notes that innovation is not a linear process from research and development through to demonstration and deployment (IPCC 2001: 355). As Mokyr (1991) explains, radical innovations and wholesale reorganisation of the techno-economic structure are less responsive to price signals than incremental innovations. Economic incentives inadequately address the issues of long timeframes and considerable uncertainty involved in the invention of new carbon-free technologies. This is why the role of pricing as the primary policy instrument for advancing this kind of technology is considered to be limited (Galiana and Green 2010). Thus, there is a need to prioritise and employ off-the-shelf technologies and approaches which can have an impact in the next decade, e.g. energy conservation and efficient use, solar thermal, wind power, passive solar heating, demand reduction (Diesendorf 2011). The upshot of these considerations is that the technological dividend may be overemphasised.

The second dividend relates to the generation of government revenues. A tax is revenue-neutral if the monies raised are completely returned to the economy via cutting other taxes or making lump-sum rebates (revenue recycling). This means that the government's budgetary position would remain unchanged. Net economic gains are possible when these revenues are used to reduce or replace distortionary taxes placed on what are regarded as economic goods (as opposed to bads) such as labour and capital (Baranzini et al. 2000; Ekins and Barker 2001; Goulder 1995; Parry 2001). A revenue-neutral tax can lower the costs of the tax system and thus produce an economic (and non-environmental) benefit. This is regarded as the strongest argument in favour of a tax compared to an ETS, which generates less public income ${ }^{5}$ (Humphreys 2007). The stability of government revenues also disappears under an ETS where market price volatility operates, speculation occurs and free permits are issued instead of being auctioned. The second dividend depends on its ability to displace pre-existing taxes or subsidies that cause inefficiencies. Thus, savings are more likely to arise if markets are already seriously distorted - e.g., labour is subject to over taxation relative to capital (Baranzini et al. 2000; Weyant 1998).

A substantial decline in the revenues from a fiscally neutral environmental tax would threaten the ability to replace revenues from distortionary taxes. Revenue flows therefore have to be non-declining (i.e., stable or rising) in order to sustain 
the economic pre-commitments to reducing other tax revenue flows and hence achieve political acceptability. This is rarely considered to be an issue, because emissions are expected to be on an indefinite rising trend and tax revenues are expected to follow (Ekins and Barker 2001). Such an assumption is, however, questionable for GHG emissions, because the aim should be to cut them drastically (i.e. by 80 per cent) if the scheme is to have the promised effect of stabilising concentrations in the upper atmosphere. The long term revenue stream would then be related only to the remaining 20 per cent of emissions.

\section{The Australian Experience}

Australia is the highest per capita emitter of $\mathrm{CO}_{2}$ globally (Australian Government 2011). Under the Kyoto Protocol, the country is allowed to increase its GHG emissions by 8 per cent above 1990 levels (418.3 $\mathrm{MtCO}_{2}$-e). By 2009, its GHG emissions had already reached 545.8 $\mathrm{MtCO}_{2}-\mathrm{e}$ (Department of Climate Change and Energy Efficiency 2011). This was an increase of around 30 per cent over 1990 levels. The Government has now pledged to reduce unilaterally its $\mathrm{CO}_{2}-$ equivalent emissions by 5 per cent from 2000 levels ( $496.1 \mathrm{MtCO}_{2}$-equivalent) by 2020, although it may increase this to 15 per cent or 25 per cent in the context of global action (Australian Government 2011). The latest scheme will cover four of the six GHGs included under the Kyoto Protocol $-\mathrm{CO}_{2}$; both methane and nitrous oxide from stationary energy, waste, rail, domestic aviation and shipping; industrial processes and fugitive emissions; and perfluorocarbon emissions from the aluminium sector (Australian Government 2011: 27-28).

The Labor Government had previously proposed a national ETS known as the 'Carbon Pollution Reduction Scheme' (CPRS) (Australian Government 2008). Under the CPRS, emission permits would have been freely allocated to major polluters and trade-exposed industries, up to 95 per cent and 66 per cent of historic benchmark emissions (a grandfathering process). Coal-fired electricity generators would have received a one-off amount of free permits and the electricity generating industry as a whole was expected to benefit by $\mathrm{A} \$ 7.2$ billion. The CPRS allowed purchase of unlimited quantities of Kyoto emissions credits from overseas. The proposal disappointed economists for varying reasons (Jotzo and Betz 2009; Spash 2010). Ross Garnaut, who originally recommended this cap-and-trade framework to the Labor Government, condemned the CPRS as 'an overly generous deal for business' secured by 'a massive lobbying exercise by vested interests' (Alexander 2008). Despite polarisation of public opinion, the CPRS managed to gain support from the majority (58 per cent) of Australians (Pietsch and McAllister 2010). However, in November 2009, the CPRS was withdrawn after being voted down for a second time in the Senate. The Government decided to delay permanently further attempts at introduction.

This major policy failure damaged the reputation of the then Prime Minister, Kevin Rudd, who led the CPRS campaign. After a failed attempt to get a tax on mining he was forced by his own party to relinquish his office in June 2010. The Leader of the Opposition, who opposed any GHG tax or price, almost won the ensuing federal election, which resulted in a hung parliament. The incumbent Prime Minister, Julia Gillard, managed to form a minority government supported by 
Greens and Independents. In July 2010, she had called for a high-profile 'citizens' assembly' as part of her election promise to gain community consensus on a GHG mitigation policy. However, after the elections, the 'citizens' assembly' concept was abandoned. Instead a Multi-Party Climate Change Committee - including Greens and Independents - was given the task of producing a policy response to Australia's ever increasing GHG emissions (The Australian 2010).

In July 2011, this committee launched its centrepiece, the 'Clean Energy Plan' (CEP) (Australian Government 2011), which passed through the Senate on 7 November 2011. This is an energy policy package including elements of a $\mathrm{CO}_{2}$-equivalent tax aimed at meeting minimal national GHG emissions targets. Around 500 big polluting companies will need to buy and surrender to the Government a permit for every tonne of $\mathrm{CO}_{2}$-equivalent they produce. ${ }^{6}$ For the first three years, the charge for these permits will be fixed, initially at A \$23 per tonne in 2012 rising to A\$25.4 in 2015 (Australian Government 2011: 21). Permits purchased at the fixed tax rate will be surrendered automatically and cannot be traded or banked. The quantity of these permits available for purchase is unlimited.

Starting from July 2015, the Government will enforce a cap on annual emissions and issue a limited number of emission permits accordingly. Trading of permits will be allowed with access to international GHG emissions markets. The $\mathrm{CO}_{2}$-equivalent tax charge will no longer be operative but rather a floating price will be set in the financial exchange markets. This means that the $\mathrm{CO}_{2}$-equivalent tax is merely a transitional measure to pave the way for an ETS.

\section{Repeating the Design Failures of the CPRS}

The CEP has been advanced as a pro-growth strategy for Australia in transition to a greener economy. However, households and small businesses are not subject to any direct obligations. Emissions from agricultural activities, private transport and light commercial vehicles are excluded from the carbon price. ${ }^{7}$ The most energy-intensive, trade-exposed industries - including aluminium production and petroleum refining - will be provided with financial assistance equivalent to 94.5 per cent shielding from the carbon price, and 66 per cent shielding for the less intensive and less exposed, such as food production (Australian Government 2011: 55). The assistance package sets levels of compensation for five years designed to support 'future investment and growth in these industries' (Australian Government 2011: 56). This amounts to distortionary subsidies via free allocation of emission permits on the basis of grandfathering.

All permits could have been designated for auctioning with the revenues going to the public purse, which would allow reduction of discretionary taxes or targeting at infrastructure change for GHG reduction. However, the political preference has always been for giving away permits to big polluters (Spash 2010). Worse, in this case, the permits are to be allocated on the basis of what polluters themselves claim, risking over-allocation and a collapse of the trading system with little or no abatement. This is exactly the situation arising under Phase I of the EU ETS where permits prices fell dramatically. Grubb et al. (2005: 135) have noted that European industry played a major role in weakening Phase I 
allocations bringing the credibility of emissions trading as an effective instrument into question.

Despite Europe's unsuccessful experiences, a permit system remains the priority of the Australian Labor Government. One key reason is easy access to cheap international credits which allow avoidance of domestic abatement, i.e., carbon-equivalent offsets. Rich countries, where domestic abatement costs are relatively high, may purchase GHG credits from poorer countries, where abatement costs are lower. These credits are based upon foreign projects which are disassociated from the domestic polluting source and are meant to either reduce GHG emissions or increase the capacity of a sink (such as forests) to absorb GHG emissions. The CEP accepts GHG credits produced by offset projects falling under Clean Development Mechanism and Joint Implementation associated with the Kyoto Protocol, but also leaves open accepting any other international units (Australian Government 2011: 107).

The idea of offsetting raises a range of issues, such as physical equivalence, welfare compensation, the quality of the projects in meeting non-GHG social and environmental standards, and the exploitation of the poor (Lohmann 2006; Spash 2010). Under the previous CPRS, there was scant regard by the ruling Labor Party for such issues and they even made this officially explicit, stating: 'The Government does not consider it necessary to accept only those CERs that meet additional criteria, such as the Gold Standard ... neither does it consider that it should assess the broader environmental and social impacts of CERs' (Australian Government 2008a: 11-12). Under the CEP, this position is maintained, with the Treasury indicating confidence in output growth in the energy-intensive industries due to their ability to buy cheap credits abroad (Treasury 2011: 111).

The Kyoto Protocol specifies offsets be supplementary to domestic action. The Marrakesh Accords ${ }^{8}$, which elaborate on the rules for offsets, state that '.. use of the mechanisms shall be supplemental to domestic action and that domestic action shall thus constitute a significant element of the effort made by each party included in Annex I to meet its quantified emission limitation and reduction commitments. The CEP has included very lax restrictions allowing internationally sourced credits to meet up to 50 per cent of a polluters compliance obligation (Australian Government 2011: 107). As a result, the projected aggregate domestic contributions do not constitute 'a significant element'. Even with the carbon tax and ETS, domestic emissions are estimated to rise from 578 $\mathrm{Mt} \mathrm{CO}_{2}$-equivalent to $612 \mathrm{Mt} \mathrm{CO}_{2}$-equivalent between 2010 and 2020 (Treasury 2011: 86). To meet the prescribed 5 per cent reduction target by 2020, Australia's emissions need to fall by $152 \mathrm{Mt} \mathrm{CO}_{2}$-equivalent. This reduction is estimated to include $58 \mathrm{Mt} \mathrm{CO}_{2}$-equivalent of domestic abatement and $94 \mathrm{Mt} \mathrm{CO}_{2}$-equivalent international abatement (Australian Government 2011: 91). So rather than even 50 per cent domestic abatement, the planned amount is only 38 per cent of the 5 per cent reduction. 


\section{Windfall Profits for Big Polluters}

Australian corporations have exploited concerns about economic recession by claiming, as they did for Rudd's proposed supertax on mining, that they will leave the country if the $\mathrm{CO}_{2}$-equivalent tax is introduced. The Australian Workers' Union has stressed that they would withdraw their support for the proposed CEP measures if jobs were threatened in emission-intensive industries (The Age 2011).

These kinds of arguments ignore the fact that current market prices are artificial, distorted and wasteful of resources - for example, by preventing the creation of jobs in cleaner industries. Such alternative resource use is easily neglected because industries that do not yet exist in any substantive form lack political or financial power to match existing corporate and union interests. As a result, the terms of the Australian debate are dictated by powerful vested interest groups.

The CEP is based on full acceptance of the industry flight argument and about risks of 'carbon leakage' - the relocation of polluters to countries with weaker regulation. A 'Jobs and Competitiveness Program', designed to 'reduce this risk', offers eligibility to activities that include aluminium production, steel manufacturing, pulp and paper manufacturing, glass making, cement production and petroleum refining (Australian Government 2011: 53-54).

The Australian scheme contradicts the standard theory of emission taxes in its treatment of energy-intensive industries. Free allocation of emission permits to these industries will start from the initial 'tax' period in 2012. In this period, holders of freely allocated permits will be allowed to sell unused permits to the Government at a fixed value (Australian Government 2011: 103). Also, excess freely allocated permits can be traded, whereas those that are purchased (mainly by less energy-intensive industries) cannot (ibid). This appears to offer a better deal for the big polluters than the former CPRS proposal under which they could only sell at a floating market price.

Allocating permits for free to corporations provides them with an incentive to pass on the cost to consumers to reap windfall profits. Even if an industry receives emission permits free of charge, the price of its products typically rise to reflect the value of the permits (Whitesell 2011). This is because free permits have an opportunity cost: excess permits can be sold in the market. By producing another unit of output, a firm gives up this option to cover the emissions from producing that unit. A firm would produce another unit of output only if it could sell that unit at a price high enough to recoup both the cost of production and the opportunity cost of surrendering the necessary permits. Therefore, output prices rise to reflect the value of permits and consumers pay for the permits that firms get for free (Whitesell 2011). For example, under the EU ETS, Europe's largest emitter, the German power company RWE, is estimated to have made $€ 1.8$ billion in one year by charging customers for permits it received for free (Lohmann 2006: 91). 
In markets, prices go up and down. The fixed value offer, however, precludes any downward adjustment (though upward adjustment has been scheduled to allow for inflation). If a firm continues to produce and emit GHGs, it will raise output prices above the fixed value level and surrender permits; if it does not produce and discharge GHG emissions, it can sell the excess permits at the guaranteed rate at no risk or cost. The fixed value mechanism removes market uncertainty and allows holders of free permits to earn windfall profits whether they curb their emissions levels or not (unless there is additional intervention e.g. by a utility price regulator). Under a normal pollution tax firms would be obliged to pay a tax or reduce pollution. In the fixed value period of the CEP, highly polluting firms are paid and have no obligation to limit emission.

\section{Permanent Tax Cuts Under Volatile Prices: A Budgetary Risk}

Emission trading is far more susceptible to opportunistic market operations and speculators leading to highly volatile prices (Spash 2010). It is therefore harder to maintain non-declining cash inflows to support a fixed amount of revenue recycling. Revenues from a pollution tax are normally expected to be more stable than from an ETS because the government sets the tax rate not the market. The quantity of emissions is then the main determinant of revenues. Once the tax rate has been raised sufficiently to reduce emissions to the target level the revenues should be stable. Other things remaining the same, the main concern with respect to revenue volatility comes from unforeseen political adjustments to the tax rate (OECD 2009). A GHG tax mechanism based on a fixed or increasing rate is then generally regarded as a better self-funding basis for committing to new long-term tax cuts and expenditures.

Once the CEP moves into the ETS stage, the revenues would depend on the trade price of permits and be subject to fluctuations in the international GHG markets. Revenue stability would then be lower than under a genuine GHG tax. Despite this, the Australian Government is promising a package of budget commitments. The household assistance package will require 63 per cent of the projected revenues from the sale of permits, and 'will be permanent and increase over time' (Australian Government 2011:39). Job support measures in the form of free permits are guaranteed for several years and subject to regulatory review afterwards. Once instigated, terminating the free allocation arrangements is likely to prove politically difficult.

Fiscal forecasts undertaken by the Government have already revealed that the CEP needs support from other tax sources. As shown in Table 1, the net fiscal impact will be positive for just one year of the tax period. The net impact is estimated to be a cost to the Treasury of approximately $A \$ 4$ billion after the ETS commences, suggesting a perpetual deficit from the scheme. Factors contributing to such a deficit might include political pressure for the continuation of free permit allocations (already estimated at over $\mathrm{A} \$ 9.2$ billion $^{9}$, or 38 per cent of the revenues from permit sales). 
Table 1: Estimated fiscal impact of the Clean Energy Plan

\begin{tabular}{lrrrrr}
\hline & \multicolumn{5}{c}{$\begin{array}{c}\text { Fiscal Impact } \\
\text { (millions of Australian dollars) }\end{array}$} \\
Revenue from sale of permits & $\underline{2011-12}$ & $\underline{2012-13}$ & $\underline{2013-14}$ & $\underline{2014-15}$ & Total \\
Fuel tax credit reductions & 0 & 7740 & 8140 & 8590 & 24470 \\
Revenue from application of other measures & 0 & 570 & 620 & 670 & 1860 \\
Governance & 0 & 290 & 320 & 320 & 930 \\
Clean Energy Finance Corporation & -78 & -90 & -106 & -107 & -382 \\
Land and biodiversity measures & -2 & -21 & -467 & -455 & -944 \\
Energy security and transformation & -69 & -131 & -506 & -489 & -1194 \\
Support for jobs & -1009 & -1 & -1003 & -1042 & -3054 \\
Household assistance measures & -26 & -3017 & -3475 & -3773 & -10291 \\
Total impact & -1533 & -4196 & -4802 & -4825 & -15356 \\
\hline
\end{tabular}

Adapted from Australian Government (2011: 131)

The revenue estimates may, moreover, be an overestimation. Treasury estimates (2011: 89) assume that carbon prices rise by 5 per cent per year plus inflation from the start of the ETS to 2050. Yet prices will be linked to international markets, which, like any international commodity market, are volatile. Under Phase I of the EU ETS, for example, the trade price of emission permits fell from $€ 30$ to $€ 12$ from April to May 2006, eventually reaching a low of $€ 0.1$ (Skjærseth and Wettestad 2008: 276, 280). Price plunges can be avoided by setting a price floor. The CEP has such a built-in price control mechanism to prevent the carbon price from falling below $\mathrm{A} \$ 15$. In addition, a price ceiling is to be set at $\mathrm{A} \$ 20$ higher than the expected international carbon price at the start of the ETS in July 2015. Both are expected to increase but are also subject to regulatory review after three years.

Clearly the need for control of the vagaries of market prices in this way shows the fallacy of the argument that markets are the best means of regulation and can be left to their own devices. The ETS is of necessity nothing like an unregulated market. In Europe failure to control market volatility, fraud and speculators has proven extremely expensive and raised awareness of the need for tight regulation, which raises the costs of the whole mechanism and removes its supposed free market qualities (Spash 2010).

\section{Prices and Technical Innovations}

Even if permit prices increase in real terms, the price signal may not constitute an effective driver of technical change toward emissions reduction as neoclassical economists suggest. Prospects for net reduction in energy use amongst households, due to price increase are uncertain as the tax cuts will raise the demand of consumer goods which may offset the intended effect of price-induced energy 
conservation. A frequently stated perspective is that markets enable a demand pull as prices create a demand-driven, profit-based incentive for the private sector to invest in new, low-emission innovations (Newell 2010). This has been taken as a strong case for 'putting a price on carbon' as the Australian government attempts to deploy such a supposedly market-based approach. Higher GHG prices are expected to give 'economic impetus' to the research and development of less-polluting modes of production and consumption (Australian Government 2011: 32). The claim is then made that a carbon price will 'harness the power of markets' to kick-start the desired transformation of the economy.

Yet the neoclassical economic approach has not been very useful for describing the process of technological innovation for GHG mitigation (IPCC 2001). Mokyr (1991) argues that technological change is the consequence of a combination of highly stochastic disturbances and a deterministic selection mechanism. Basic innovations create new techniques and tend to be abrupt and discontinuous, whereas incremental innovations are more likely to respond to factor prices in a predictable way. Substantial cuts in GHG emissions require removing fossil fuels from industrial countries: incremental innovations are insufficient inducement (OECD 2010).

Raising the cost of GHGs would be more effective in inducing the deployment of 'on-the-shelf' technologies than those that require further basic research, such as carbon emission-free technologies (Galiana and Green 2010). For this type of technology, 'the development costs may be greater, the time horizons longer, the uncertainty larger and the supply of investors small' (OECD 2010: 83). The initial three-year fixed value period of the CEP merely provides short-term certainty that is not likely to be a strong inducement to undertake even medium term incremental innovations, let alone long-term, risky and uncertain investments in the development of new technologies.

The CEP in part recognises this problem by including separate funds for investment in cleaner technologies. A Clean Energy Finance Corporation will be established to invest in businesses seeking funds to develop renewable energy and energy efficiency technologies. The Corporation will be commercially oriented and chaired by a banker. Yet, this raises concerns as to how costs and benefits will be evaluated for long-term, risky investments in basic innovations for emission reduction that tend to yield limited short-term profits and non-financial environmental and social returns.

An Energy Security Fund will be set up to assist highly polluting electricity generators to replace their high emission facilities with cleaner technologies. This in effect rewards past pollution activities. It involves free allocation of emission permits plus cash equivalent to $\mathrm{A} \$ 5.5$ billion (nominal) over 6 years (Australian Government 2011: 75). The amount of over $\mathrm{A} \$ 9$ billion in subsidies given to major GHG emitters is more than double the amount allocated to the two clean technology initiatives (see Table 1). As the free permits are used to support growth in energy-intensive industries, they are effectively a form of energy subsidy which undoes the incentives of an increasing GHG cost. 


\section{The CEP - A 'Great Reform Agenda'?}

According to the Australian Government (2011) the proposed CEP scheme, combined with its Renewable Energy Target, will invest A \$20 billion in renewable energy. In addition, the commercially oriented Clean Energy Finance Corporation will be allocated $\$ 10$ billion to invest in renewable energy and innovative technologies to cut pollution. The Australian Renewable Energy Agency will administer $\mathrm{A} \$ 3.2$ billion. The outcome of this $\mathrm{A} \$ 33$ billion allocation is expected to be that 'the equivalent of 20 per cent of Australia's electricity will come from renewable sources by 2020' (ibid). As current renewable electricity production is 8 per cent (Australian Government 2011: 71), this means just a 12 per cent increase in renewable electricity production. No new public assets will be created from this outlay because all monies are going to fund private enterprise, commercial interests, and corporations. In addition to this $\mathrm{A} \$ 33$ billion a further $\mathrm{A} \$ 14$ billion appears to be allocated to the worst polluters. The billions to be spent on paying the coal industry to close its most polluting plants will be reinvested by that industry, which will be able to plead for money and cheap loans under the security fund. So the public sector will be financing and underwriting private profits.

The scheme is trapped in neo-liberal market rhetoric. Unwillingness to impose regulatory controls has resulted in a complex system of benefits and allowances for polluters that is in fact heavily regulated. We are told: 'A carbon price is the most environmentally effective and economically efficient way to reduce pollution' (Australian Government 2011:21). Yet what changes are expected from the scheme? According to the CEP the types of changes a 'carbon price' can deliver are:

- Promoting more gas-fired or renewable electricity generation;

- Converting coal-fired boilers to gas-fired boilers in manufacturing plants, commercial buildings and hospitals;

- Making energy-efficient buildings more attractive to tenants;

- Providing an incentive for households and businesses to use energy more wisely;

- Prompting innovation in technology to reduce pollution from existing processes;

- encouraging chemical plants to install scrubbers to reduce nitrous oxide emissions;

- encouraging the installation of more efficient motors in industry;

- encouraging the capture and use or flaring of emissions from mining and gas extraction (Australian Government 2011: 22-23).

This 'light touch' regulation involves lots of 'encouraging', and some 'prompting', 'promoting' and 'providing', without any certainty that any change will materialise. Fossil fuel dependence is likely to be maintained, with conversion of gas to electricity expected to increase by over 200 per cent by 2050 (Australian Government 2011: 24) - hardly a shift to sustainability. In terms of effectiveness, attempts 
to create artificial markets and rely upon highly volatile commodity prices are less effective than the alternative of best available technology regulation or the setting of energy efficient standards for products and housing.

The efficiency claim is also unproven and unprovable. This has been explained at length by Spash (2010) for ETS applications to climate change. Basically economists cannot predict the operation of real markets or the impacts of their schemes on future prices and this is especially the case for an all pervasive charge such as a change in energy prices. What is being dressed-up as efficiency is the purchase of cheap international permits from exploiting the poor, and from providers who do not enforce the same labour, social, environmental, welfare, health and safety standards as found domestically. In any other areas, this would be deemed unfair competition and unethical behaviour such as the buying of cheap products from sweat shops or child labourers.

Rather than directly addressing the need for domestic restructuring (both societal and economic) the trend in the current GHG control debate is to avoid the issue through simplistic reliance on price solutions through unregulated markets. The strong neo-liberal opposition to taxes has put GHG taxes beyond the political pale as a 'Touch it and die' solution (Harrison 2010: 522).

The use of the revenues from pollution taxes to compensate polluters can easily destroy the incentives meant to be created and allow polluters to continue business as usual (Enevoldsen 2005). Weyant (1998) doubts the ability of governments to use the revenues in an efficient or appropriate way. Evidence suggests that historically the revenues are often earmarked towards distortionary projects or returned to the general budget, rather than recycled (Hahn 2009) and this limits the expected double dividend (Bovenberg and Goulder 1996).

In a neo-liberal political climate, making a GHG tax acceptable requires assuring the electorate and industry of minimal negative economic impacts or even positive growth. The CEP is no different in this respect. Treasury modelling estimates suggest that under the $\left(\mathrm{CO}_{2}\right.$-equivalent $)$ carbon price: incomes will grow 16 per cent by 2019-20 and 54 per cent by 2050 and 1.6 million jobs will be created by 2020 (Australian Government 2011: 24). From an environmental perspective, this pro-growth position appears highly problematic. How is the absolute expansion in the scale of the (basically unrestructured) economy going to prevent increases in material and energy throughput, which are directly responsible for resource extraction, waste and pollution going into the environment? There is no real vision here of a sustainable economy, decoupling economic activity from fossil fuels or assessment of the basis upon which current economic growth occurs and is being sustained. Of course, growth without increased GHG emissions is not actually the aim of the CEP, which is to reduce the rate of GHG emissions increases rather than to reduce their absolute level. The Australian Government's plans have little relevance for contributing towards the stabilisation of GHGs in the upper atmosphere, let alone at a level scientists state would avoid human induced climate change.

What is really required to move Australia off its coal fired electricity generation and avoid substitution by other polluting sources such as nuclear or gas? Research by Beyond Zero Emission (2010), a not-for-profit organisation associ- 
ated with researchers from the University of Melbourne, shows that Australia can achieve 100 per cent renewable electricity generation within a decade using technology that is commercially available now to totally replace base load power currently sourced from fossil fuels. Wind power and solar thermal with molten salt storage have the capacity to supply 60 per cent and 40 per cent of Australia's electricity respectively. They estimate this will require an investment of $A \$ 370$ billion over ten years, stated to be equivalent to costing A $\$ 8$ per household per week. They project that the investment will generate a stimulus to the Australian economy that is equivalent to 3 per cent of GDP over ten years and create permanent jobs around four times higher than currently exist in the domestic fossil fuel sector (Beyond Zero Emissions 2010). Converting the 92 per cent of Australian electricity not generated from renewable energy is technically feasible with existing technology and could be funded by a real GHG tax.

\section{Conclusions}

A pollution tax is meant to impose a cost per unit of emissions on the producer. Polluters should then pay for emissions they continue to release plus the cost of any emissions control they undertake. The idealised economic planner is an all-knowing, all-powerful guardian of the public interest unswayed by special interest pleadings, and would carefully calculate the point where the marginal costs of intervention just offset the benefits and then set a tax rate to maximise efficiency. In this idealised world, firms are price takers with no market or political power. The design of a pollution tax is assumed to be driven by environmental considerations in light of economic theory immune from political influences.

In reality, non-environmental political and economic considerations dominate environmental regulation and its design. This is especially true in countries with the biggest fossil fuel dependencies and unquestioning support for modern consumerist lifestyles. That mainstream economics is unable to explain the political economy in which we live helps explain why regulation using market-based approaches has repeatedly failed to achieve any substantial GHG emissions reductions. Economic theory needs to take account of the risks posed by large corporations to democratic governance.

All regulatory and public policy instruments are subject to political negotiation and vested interests. While taxes favour government, they can also be watered down and counterproductive. Substantial concessions to polluting industries in the form of tax exemptions, reductions and rebates to maintain momentum for material growth may appear in design proposals and be justified as being necessary in hard economic times. Highly polluting industries may then be able to gain more concessions than the less polluting ones. Thus GHG taxes can become primarily targeted at securing votes and jobs, and not only fail to correspond to text-book recommendations but also fail to achieve the promised internalisation of social and environmental costs.

In proposing a temporary $\mathrm{CO}_{2}$-equivalent tax, Australia is developing its own model, departing from some of the defining principles of a pollution tax. Correctly designed, a GHG emission tax could provide more pollution-control-cost certainty than an ETS and have greater capacity for revenue recycling. As the 
proposed GHG tax is a short prelude to an ETS, any such certainty will be absent after three years. The scale of concessions to industry is such that the basic logic of the Pigovian tax appears reversed. Big polluters are rewarded and subsidised, with rewards directly proportional to the scale of pollution. Less energy-intensive industries will be penalised by having to purchase non-tradable permits at a fixed value, whereas the more energy-intensive industries are bestowed tradable permits for free and allowed to sell them. Australia exemplifies how the rich and powerful polluters have been able to take control of the debate on human induced climate change, manipulating it to their considerable financial advantage, while pretending to be the victims of an environmental hoax.

\section{Notes}

1. This article has been adapted from an unpublished paper of the same name, deposited in 2011 in MPRA, the Munich, Personal RePEc (Research Papers in Economics) Archive, available: http://mpra.ub.uni-muenchen.de/33997/.

2. In 2009, Australia overtook the USA (see http://www.abc.net.au/news/sto ries/2009/11/18/2745751.htm). Amongst OECD countries, Australia is the highest per capita emitter of all GHGs combined (see http://www.garnau treview.org.au/chp7.htm).

3. Australia only ratified the treaty in 2008 after a change of national government from Howard's conservatives to Rudd's Labor Party.

4. GHG taxation tends to be regressive as it is likely to disproportionately affect lower-income households than the higher-income.

5. An emission trading system in which all emission permits are freely allocated generates no revenue for government. Instead, money flows from polluters to organisations who receive the permits. Free allocation of permits has been a common practice of existing ETS design and implementation (Spash 2010).

6. Under the CPRS, 1000 firms were to be targeted.

7. Australian farmers will not be required to pay for the GHG pollution created by their agricultural activities, but will be involved in the ETS as a provider of carbon-equivalent credits that can be sold to companies with liabilities under the ETS to offset their pollution.

8. The Marrakesh Accords are the aggregate Decisions (2/CP.7 through to 24/ CP.7) of the Conference of the Parties to the UNFCCC set down in its seventh session, held at Marrakesh, Morocco from 29 October to 10 November 2001. Those decisions were adopted in Montreal in November 2005.

\section{References}

Alexander, C. (2008) 'Ross Garnaut savages Government over climate scheme', Herald Sun, 20 December, available: http://www.heraldsun.com.au/news/national/ garnaut-climate-barrage/story-e6frf7l6-1111118370207 [accessed 10 February 2012].

Australian Government (2008) Carbon Pollution Reduction Scheme: Australia's Low Pollution Future, Volume 1, White Paper, December, Commonwealth of Australia, Canberra. 
Australian Government (2011) Securing a clean energy future: The Australian Government's climate change plan, available: http://www.cleanenergyfuture.gov. au/wp-content/uploads/2011/07/Consolidated-Final.pdf [accessed 10 January 2012].

Baranzini, A., Goldemberg, J. and Speck, S. (2000) 'A future for carbon taxes', Ecological Economics, 32(3), pp. 395-412.

Beyond Zero Emissions (2010) Australian Sustainable Energy: Zero Carbon Australia Stationary Energy Plan - Synopsis, Energy Research Institute, University of Melbourne, Melbourne.

Bovenberg, A. L. and Goulder, L. H. (1996) 'Optimal environmental taxation in the presence of other taxes: General-equilibrium analyses', American Economic Review, 86(4), pp. 985-1000.

Combet, Hon. G. (2011) Garnaut Review 2011; Carbon price policy, Transcript, Interview on MTR 1377 with Steve Price, 1 June, available: http://www.climate change.gov.au/minister/gregcombet/2011/transcripts/June/tr20110601.aspx [accessed 2 October 2011].

Department of Climate Change and Energy Efficiency (2011) National Greenhouse Gas Inventory: Accounting for the Kyoto Target, December Quarter 2010, April, Commonwealth of Australia, Canberra.

Diesendorf, M. (2011) 'Redesigning energy systems' in J. S. Dryzek, R. B. Norgaard and D. Schlosberg (eds.) The Oxford Handboook of Climate Change and Society, Oxford University Press, Oxford, pp. 561-579.

Ekins, P. and Barker, T. (2001) 'Carbon taxes and carbon emissions trading', Journal of Economic Surveys, 15(3), pp. 325-376.

Enevoldsen, M. (2005) The Theory of Environmental Agreements and Taxes: $\mathrm{CO}_{2}$ Policy Performance in Comparative Perspective, Edward Elgar, Cheltenham, England.

Fischer, C. (2003) 'Climate change policy choices and technical innovation', Minerals and Energy - Raw Materials Report, 18, pp. 7-15.

Galiana, I. and Green, C. (2010) 'Technology-led climate policy' in B. Lomborg (ed.) Smart Solutions to Climate Change: Comparing Costs and Benefits, Cambridge University Press, Cambridge, pp. 292-338.

Gillard, J. (2011) A great clean energy future, a great reform agenda, Speech to National Press Club, 14 July, available: http://www.sweetspeeches.com/s/2592-ju lia-eileen-gillard-a-great-clean-energy-future-a-great-reform-agenda [accessed 10 February 2012].

Goulder, L. H. (1995) 'Environmental taxation and the double dividend: A reader's guide', International Tax and Public Finance, 2(2), pp. 157-183.

Grubb, M., Azar, C. and Persson, U. M. (2005) 'Allowance allocation in the European emissions trading system: A commentary', Climate Policy, 5(1), pp. 127-136.

Hahn, R.W. (2009) 'Greenhouse gas auctions and taxes: Some political economy considerations', Review of Environmental Economics and Policy, 3(2), pp.167188.

Harrison, K. (2010) 'The comparative politics of carbon taxation', Annual Review of Law and Social Science, 6, pp. 507-529. 
Humphreys, J. (2007) 'Exploring a carbon tax for Australia', CIS Policy Monograph 80, The Centre for Independent Studies, Sydney, available: http://www.cis.org. $\mathrm{au} /$ publications/policy-monographs/article/919-exploring-a-carbon-tax-foraustralia [accessed 10 February 2012].

IPCC (2001) International Panel on Climate Change, Climate Change 2001: Mitigation: Contribution of Working Group III to the Third Assessment Report of the Intergovernmental Panel on Climate Change Insitution, Cambridge.

Jaffe, A. B. and Stavins, R. N. (1995) 'Dynamic incentives of environmental regulations: The effects of alternative policy instruments on technology diffusion', Journal of Environmental Economics and Management, 29(3), S43-S63.

Jotzo, F. and Betz, R. (2009) 'Australia's emissions trading scheme: Opportunities and obstacles for linking', Climate Policy, 9(4), pp. 402-414.

Lohmann, L. (2006) 'Carbon trading: A critical conversation on climate change, privatisation and power', Development Dialogue, 48, Dag Hammarskjöld Centre, Uppsala, p. 91.

Löschel, A. (2002) 'Technological change in economic models of environmental policy: A survey', Ecological Economics, 43 (2-3), pp. 105-126.

Mokyr, J. (1991) 'Evolutionary biology, technological change and economic history', Bulletin of Economic Research, 43(2), pp. 127-149.

Newell, R. G. (2010), 'The role of markets and policies in delivering innovation for climate change mitigation', Oxford Review of Economic Policy, 26(2), pp. 253269.

Oates, W. E. (1995), 'Green taxes: Can we protect the environment and improve the tax system at the same time?', Southern Economic Journal, 61, pp. 915-922.

OECD (2009) Organisation for Economic Cooperation and Development, The Economics of Climate Change Mitigation: Policies and Options for Global Action Beyond 2012, OECD, Paris.

OECD (2010) Taxation, Innovation and the Environment, OECD, Paris.

Parry, I. W. H. (2001) 'Revenue recycling and the costs of reducing carbon emissions' in M. A. Toman (ed.) Climate Change Economics and Policy: An RFF Anthology, Resources for the Future, Washington, DC.

Parry, M., Palutikof, J., Hanson, C. and Lowe, J. (2008), 'Squaring up to reality', Nature Reports Climate Change, pp. 68-71.

Pearce, D. W. (1991) 'The role of carbon taxes in adjusting to global warming', The Economic Journal, 101, pp. 938-948.

Pietsch, J. and McAllister, I. (2010) “"A diabolical challenge”: Public opinion and climate change policy in Australia, Environmental Politics, 19(2), pp. 217-236.

Pigou, A. C. (1920) The Economics of Welfare Macmillan, London.

Popp, D. (2002) 'Induced innovation and energy prices', American Economic Review, 92(1), pp. 160-180.

Skjærseth, J. B. and Wettestad, J. (2008) 'Implementing EU emissions trading: Success or failure?', International Environmental Agreements, 8(3), pp. 275-290.

Spash, C. L. (2002) Greenhouse Economics: Value and Ethics, Routledge, London. 
Spash, C. L. (2007) 'The economics of climate change impacts à la Stern: Novel and nuanced or rhetorically restricted?', Ecological Economics, 63(4), pp. 706-713.

Spash, C. L. (2010) 'The brave new world of carbon trading', New Political Economy, 15(2), pp. 169-195.

Swan, W. (2011) Address to National Press Club, Canberra, 7 June.

The Age (2011) 'AWU backs Gillard's carbon tax', 18 July, available: http://www. theage.com.au/environment/climate-change/awu-backs-gillards-carbon-tax20110718-1hl2c.html [accessed 1 February 2012].

The Australian (2010) 'Gillard PM dumps citizens assembly as Labor, Greens strike alliance deal', 1 September, available: http://www.theaustralian.com. $\mathrm{au} /$ news/labor-greens-strike-alliance-deal-for-stable-government/storye6frg6n6-1225912672100 [accessed 1 February 2012].

Treasury (2011) Strong Growth, Low Pollution: Modelling A Carbon Price, Commonwealth of Australia, Canberra.

Weyant, J. P. (1998) 'The costs of carbon emissions reductions' in W. D. Nordhaus (ed.) Economics and Policy Issues in Climate Change, Resources for the Future, Washington, DC, pp. 191-214.

Whitesell, W. C. (2011) Climate Policy Foundations: Science and Economics with Lessons from Monetary Regulation, Cambridge University Press, New York.

\section{About the Authors}

» Professor Clive Spash holds a Chair in Public Policy and Governance in the Department of Socio-Economics, WU Vienna University of Economics and Business, Vienna. He is also a Professor II in the Department of International Environment and Development Studies at Norway's University of Life Sciences. Professor Spash is an economist who writes, teaches and conducts interdisciplinary research on public policy with an emphasis on human behaviour and environmental values, ecological economics, environmental and resource economics, applied ethics, political science and social psychology. He was formerly employed at the CSIRO in Canberra as a senior civil servant and science leader. He can be contacted through his website http://www.clivespash.org/.

» Alex Lo lectures in environmental economics and policy in the School of Environment, Griffith University, Australia. His research fields include ecological economics; environmental valuation (stated preference approaches); environmental values and behaviour; ethics and economics, the political economy of climate change; carbon pricing policies; community adaptation to climate change and deliberative policy evaluation. He can be contacted at alex.lo@ griffith.edu.au. 
